
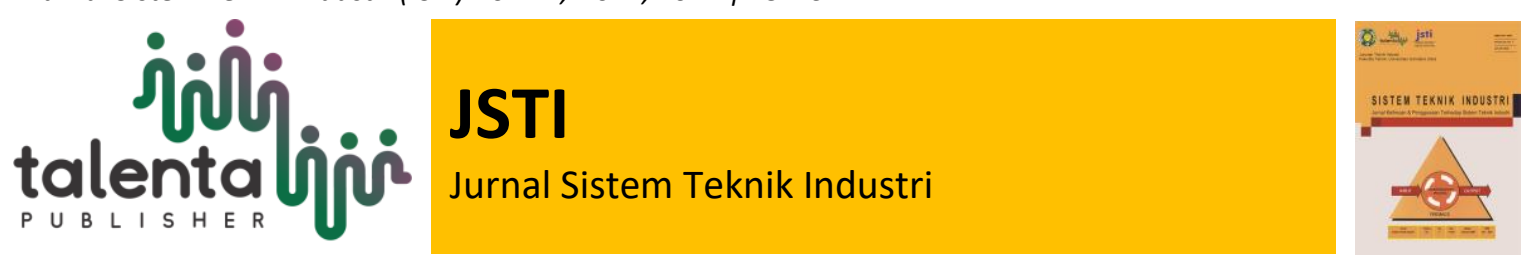

\title{
Development of Model for Technoprenuership for Students at Universitas Sumatera Utara
}

\author{
Andreasen Provicnius Chaidir', Nazaruddin ${ }^{2}$, Sugiharto Pujangkoro ${ }^{3}$ \\ ${ }^{1,2,3}$ Departement of Industrial Engineering, Universitas Sumatera Utara, Medan, Indonesia
}

\begin{abstract}
The number of entrepreneurs who are expected to become innovative industries in Indonesia only reached $0.24 \%$ of Indonesia's total population. College plays an important role in motivating young graduates to become technopreneurship. The number of innovations that arise compared to innovative product innovations is still very minimum every year. The main problem faced by students is that $52.15 \%$ of students don't continue their innovation products because they don't get funding $13.50 \%$ of students don't continue their innovation products because they don't know what to do, do, and don't get technical guidance, $11.66 \%$ of students want to graduate on time, $10.44 \%$ don't get mentors/coaches who know how to develop and guide students well, $6.75 \%$ of students that there is no incubation platform, $5.5 \%$ of students do not dare to take the risk to enter the technopreneur world. Researchers then designed a dynamic model of technopreneur incubation and simulated a design model that aims to see how far the model can help innovative products get funding. The simulation was conducted with three scenarios. The result was $17.6 \%$ increase when the incubation program was extended, an increase of $27.46 \%$ when there was an improvement in infrastructure and $21.47 \%$ when mentor capacity was lowered.
\end{abstract}

Keyword: Technoprenuer, Model, Incubation, Simulation, Dynamic model

\begin{abstract}
Abstrak. Jumlah wirausahawan yang diharapkan menjadi industri inovatif di Indonesia baru mencapai 0,24\% dari total penduduk Indonesia. Perguruan tinggi berperan penting dalam memotivasi lulusan muda untuk menjadi wirausahawan teknologi. Jumlah inovasi rintisan yang muncul dibandingkan dengan inovasi produk yang inovatif masih sangat minim setiap tahunnya. Masalah utama yang dihadapi mahasiswa adalah sebanyak 52,15\% mahasiswa tidak melanjutkan produk inovasinya karena tidak mendapatkan akses pendanaan, 13,50\% mahasiswa tidak melanjutkan produk inovasinya karena tidak tahu apa yang harus dilakukan dan dilakukan. tidak mendapatkan bimbingan teknis. 11,66\% siswa ingin lulus tepat waktu, 10,44\% tidak mendapatkan mentor/pelatih yang tahu bagaimana mengembangkan dan dapat membimbing siswa dengan baik, 6,75\% siswa bahwa tidak ada platform inkubasi, 5,5\% mahasiswa tidak berani mengambil resiko untuk memasuki dunia technopreneur. Peneliti kemudian merancang model dinamis inkubasi technopreneurship dan mensimulasikan model desain yang bertujuan untuk melihat sejauh mana model tersebut dapat membantu produk inovatif mendapatkan pendanaan. Simulasi dilakukan dengan 3 skenario. Hasilnya adalah peningkatan 17,6\% ketika program inkubasi diperpanjang, meningkat 27,46\% ketika ada peningkatan infrastruktur dan 21,47\% ketika kapasitas mentor diturunkan.
\end{abstract}

Kata Kunci: Technopreneur, Model, Inkubasi, Simulasi, Model dinamis

Received 30 November 2021 | Revised 10 December 2021 | Accepted 01 January 2022

*Corresponding author at: Jl. Almamater, Kampus USU, Medan, 20155, Indonesia.

E-mail address: andreasenpc@gmail.com

https://doi.org/10.32734/jsti.v24i1.7703 Attribution-NonCommercial-ShareAlike 4.0 International License. Some rights reserved Copyright (C 2022 Published by Talenta Publisher, ISSN: 1411-5247 e-ISSN: 2527-9408

Journal Homepage: http://talenta.usu.ac.id/jsti 


\section{Introduction}

In an effort to grow the national economy, Indonesia must increase entrepreneurs. The number of entrepreneurs (entrepreneurs) in Indonesia is $3.47 \%$ of the total population of Indonesia, which is approximately 252 million, of which the number of entrepreneurs in Indonesia is only approximately 5.7 million people. A country is said to be developed if the entrepreneur reaches $10-14 \%[1]$

The number of entrepreneurs will continue to grow along with the increasing number of government programs that encourage economic growth. Entrepreneurship and economic growth are closely and positively related. The increasing number of entrepreneurs can have an impact on increasing the economic growth of a country [2].

Along with the times, the growth of entrepreneurship is also supported by the development of better technology. So now many young entrepreneurs have started using technology in their business. The combination of these two terms forms a new term in the world of entrepreneurship, namely technopreneurship. Technopreneurship which is a combination of the words technology and entrepreneurship [3].

According to the Ministry of Research and Technology/BRIN, Bambang Brodjonegoro [4], "Currently the number of entrepreneurs who are expected to become innovative industries in Indonesia has only reached $0.24 \%$ of the total population of Indonesia when compared to Malaysia at 3\%, Singapore $7.2 \%$, China 10\%, and United States reached $11.5 \%$, With this it is concluded that Indonesia is still poor in the field of technology application in the business world.

Start-up companies are an important dimension in the process of innovation. Therefore, these enterprises are guided by business incubators throughout their growth processes, rendering them an influential instrument in promoting innovation and entrepreneurship [5]. Various studies have explored the innovation incubator in support of start-up innovation before resulting in innovation commercialization. Additionally, An incubator's core process is to support the development of incubatee's social innovation. As of recent, Wang et al.[6] Emerging economies should encourage the creation of business incubators to foster the growth of technology entrepreneurs and domestic innovation results, according to the findings

There are many models used to develop new business units that are familiar with the use of technological innovations including franchise models, partnerships, mentoring, business incubators, or patterns of entrepreneurship education in universities developed by the private sector or the government [7].

The incubator program is considered to have its own advantages because it will grow new business units that are more professional in the sense of being able to produce goods or services that have competitive value. In the incubator, prospective entrepreneurs are detrained and taught to master business aspects and are provided with technical guidance and working capital [8]. 
Universities play an important role in motivating young graduates to become technology entrepreneurs. The increasing number of entrepreneurial graduates will reduce the unemployment rate and will even increase the number of jobs For the university level, there is a place where prospective technopreneurships can develop ideas and innovations that they have innovated in lectures called Incubators. The business incubator serves to provide managerial understanding and access to capital at an early stage [9]. The business incubator also functions to accelerate the innovation process by building bridges between innovators and investors and other partners.

At the Universitas Sumatera Utara there is no part of the Innovation and Venture Business Agency whose goal is to be an institution/institution that produces high-quality innovation in Science, Technology, and Arts (IPTEKS) that can be commercialized and incubates young entrepreneurs/students on campus to improve business performance or starting their own business, especially in the technology sector can be seen in Table 1 .

Table 1 USU Student Data

\begin{tabular}{cccccc}
\hline & TA & TA & TA & TA & Total \\
& $2017-2018$ & $2018-2019$ & $2019-2020$ & $2020-2021$ & \\
\hline Active Students & 2537 & 2985 & 3386 & 3925 & 12833 \\
Inovative Product & 30 & 38 & 43 & 52 & 163 \\
$\quad$ Winning & & & & & \\
International & 9 & 27 & 19 & 20 & 75 \\
Competition & & 2 & 5 & - & 7 \\
Getting Funded & 1 & 2 & 2 & - & 5 \\
$\quad$ Start-up & 1 & & & & \\
\hline
\end{tabular}

Based on the data in Table 1, it is clear that the number of innovative start-ups that appear compared to innovative product innovations is still very minimal every year. In other words, the current student mentoring/learning program is still less successful in producing new entrepreneurs and also innovative products that transform into a start-up.

Most students who take technopreneurship classes are just looking for grades and completing courses and are not serious about creating innovative products that solve problems and have not seen the opportunities that exist in the world of technopreneurship. Students who have won the competition did not continue their product innovations.

From the problems described, it can be concluded that the current mentoring model is still not effective enough to grow new entrepreneurs.

Based on the problems faced, a model will be formed that will support the success of students to be able to develop products to transform into an innovative start-up. Given the many components that need to be involved in starting a technology-based business, it is therefore necessary to develop an integrated technopreneurship model in order to increase the success of young entrepreneurs starting from a technology-based academic university. Novelty of the research is 
the dynamic simulation the model designed which can be proven to increase the number of technopreneurships.

\section{Related Work}

Wicaksana [10] conducted a study to build a system framework for a Business Incubator in producing a new technology-based company (PPBT) at PIT UNS. Benchmarking approach was carried out on several Business Incubators that have produced PPBT. The output of this research is, PIT UNS has developed a framework for establishing a PPBT system.

Research conducted by Wulung et al. [11] is to develop a conceptual model of the incubation process. This model concentrates on combining incubators, investors, and tenants. This model provides a negotiation process to reach a win-win solution and satisfy the decision maker. The purpose of this research is that incubators can avoid budget deficits and reduce technology transfer failures, furthermore incubators can ensure that new tenants benefit. On the other hand, investors can optimize investment returns and reduce investment risk based on the uncertainty of tenant conditions.

Research conducted by Widyarini et al. [12] has the aim of knowing the factors that influence student intentions towards entrepreneurship who are able to utilize information and communication technology in business development. The hope that researchers want to get is that they can contribute to the development of entrepreneurial theory by providing empirical evidence about the factors that influence student motivation for technology-based entrepreneurship. Data were taken from UKWMS students and the data were processed using structural equation modeling (SEM). The result is that there are several factors that have a significant effect on students' intentions towards technology-based entrepreneurs.

Somsuk et al [13] conducted research on how to determine the factors that influence the success of technology-based business incubators. The data were identified based on the literature review in the perspective of resources-based view (RBV). Furthermore, the Q-Sort method is used to classify these factors based on expert opinions to generate group consensus in the classification. This research was conducted at the Thailand Science Park Incubator. The results obtained are strategic resources and their categories found as possible success factors and found using RBV theory.

\section{Methodology}

Research was conducted on technopreneurship education at Universitas Sumatera Utara which includes tecnopreneur lectures, and supporting activities as well. The respondent were the lecturers, the department, and the students in the department. This research started with literature review from books and previous research which is stated in related work then continued by data was collected through observation, and interviews, data was analyzed and continued by variable 
identification then a model is designed continued by verification and validation with experts and the model is simulated to get the result. The research method can be seen in Figure 1.

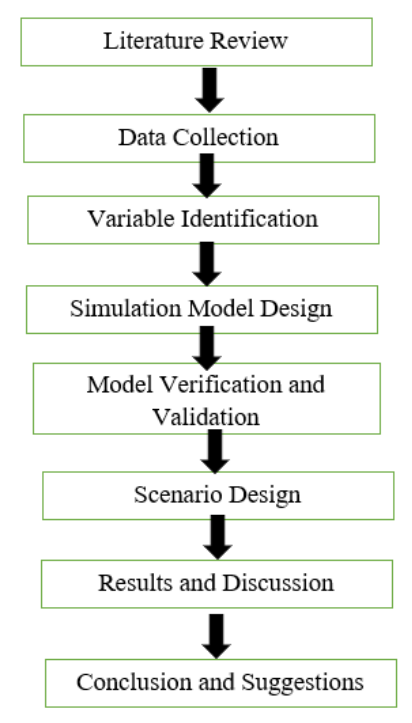

Figure 1 Research Method

\section{Result and Discussion}

Technopreneurship learning is given to students in each study program with the hope that students understand the meaning of entrepreneurship and technopreneurship and are required to produce an output in the form of a product prototype. The technopreneurship learning scheme can be seen in Figure 2.

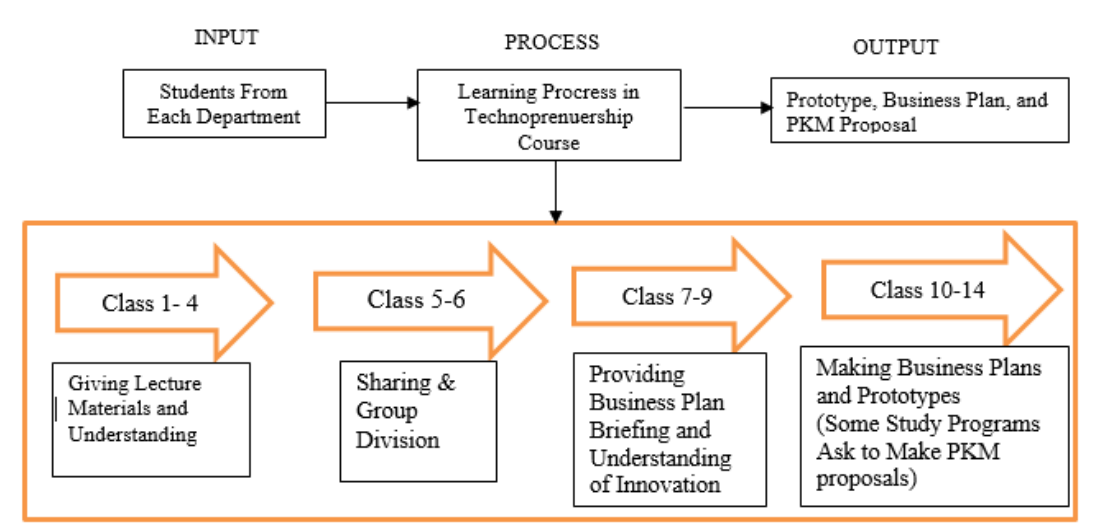

Figure 2 Technopreneurship learning scheme for most of the faculty curently

Most students who take technopreneurship classes are just looking for grades and completing courses and are not serious about creating innovative products that solve problems and have not seen the opportunities that exist in the world of technopreneurship. Students who have won the competition did not continue their product innovations. 
Interview has been done to the 163 innovative product on why they are not to continue their innovation and the result can be seen in Table 2 .

Table 2 Students Problem

\begin{tabular}{llll}
\hline & Problems & Number of Students & Pecentage \\
\hline 1 & No Funding & 85 & $52,15 \%$ \\
2 & No Technical Support & 22 & $13,50 \%$ \\
3 & Want to Graduate on Time & 19 & $11,66 \%$ \\
4 & No Mentor/Coach & 17 & $10,44 \%$ \\
5 & No Business Incubation & 11 & $6,75 \%$ \\
6 & Not Willing to Take Risk & 9 & $5,5 \%$ \\
\hline & Total & $\mathbf{1 6 3}$ & $\mathbf{1 0 0 \%}$ \\
\hline
\end{tabular}

As many as $52.15 \%$ of students did not continue their innovation products because they did not get access to funding, $13.50 \%$ of students did not continue their innovation products because they did not know what to do and did not get technical guidance. $11.66 \%$ of students want to graduate on time, $10.44 \%$ do not get a mentor/coach who knows how to develop and can guide students well to get technopreneurship, $6.75 \%$ of students answered that there is no incubation platform like in universities Another high, 5.5\% of students do not dare to take risks to enter the world of technopreneurship.

Therefore, model will be created and choose the appropriate strategy to be used in the development of technopreneurship at the Universitas Sumatera Utara in order to increase the number of innovative products that get funding to run their business.

Based on the Figure 2 scheme, it can be seen that no follow-up has been done to students who have produced innovative products because there is no special responsible incubator to help guide students to perfect prototypes and there is no guidance program for students to improve their understanding of business and innovation products therefore the follow up scheme has been designed and can be seen in Figure 3 


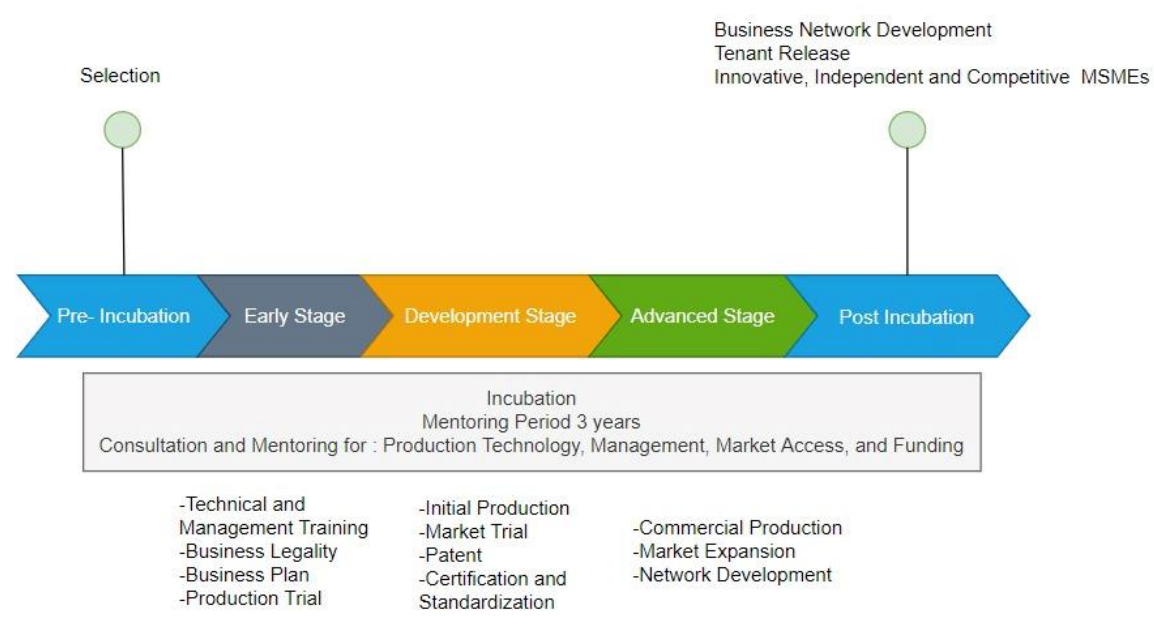

Figure 3 Follow Up on Technopreneurship Learning

The model will be simulated using the AnyLogic application to see the number of products that will pass the incubation and get funding and the amount of funds needed to run an innovative product business that will be made. The model then was verified and validated by brainstorming and discussion with the expert in their field. The simulation model can be seen in Figure 4.

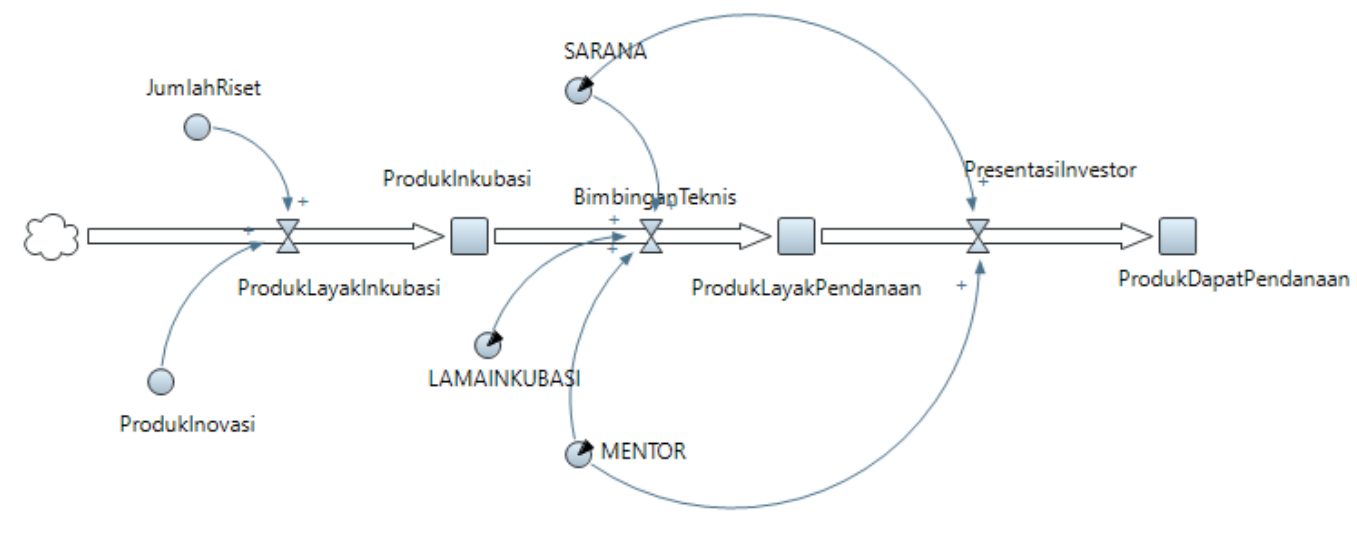

Figure 4 Technopreneurship Incubation Simulation Model, Universitas Sumatera Utara

Simulation has been done in 3 scenarios to see which is produce the best result. Scenario 1 is to increase the incubation time. Scenario 2 is to increase infrastructure for students, and Scenario 3 is to reduce the mentor capacity. The result of the simulation can be seen in Table 3 .

Table 3 Simulation Result

\begin{tabular}{cccccc}
\hline & & \multicolumn{4}{c}{ Product Getting Funded } \\
\hline \multirow{2}{*}{ Year } & $\begin{array}{c}\text { Inovative } \\
\text { Product }\end{array}$ & Existing & Scenario & Scenario & Scenario \\
& 163 & 30 & $\mathbf{1}$ & $\mathbf{2}$ & $\mathbf{3}$ \\
\hline $\mathbf{2 0 2 1}$ & 188 & 47 & 64 & 55 & 52 \\
$\mathbf{2 0 2 2}$ & 195 & 58 & 78 & 63 & 59 \\
$\mathbf{2 0 2 3}$ & 195 & & & & 65
\end{tabular}




\begin{tabular}{cccccc}
$\mathbf{2 0 2 4}$ & 220 & 66 & 89 & 78 & 70 \\
$\mathbf{2 0 2 5}$ & 257 & 71 & 103 & 97 & 99 \\
\hline Total & $\mathbf{2 8 4}$ & $\mathbf{3 3 4}$ & $\mathbf{3 6 2}$ & $\mathbf{3 4 5}$ \\
\hline Percentage Increase & & $\mathbf{1 7 , 6 \%}$ & $\mathbf{2 7 , 4 6 \%}$ & $\mathbf{2 1 , 4 7 \%}$ \\
\hline
\end{tabular}

Students have been good at making new innovative products especially the engineering and science course students but they lack of management skills therefore there is a need to equip those students with some managerial and economic skills so they can transform their product to business.

In reseach conducted by Widyiarini [9] it is said that students with interest in technoprenuers have more chances of succeed and that is true if their product get funded and they have and adequate infrastructure. In the research done by Somsuk [10] stated that infrastructure play an important role in the success of technopreneurships.

In Universitas Sumatera Utara there is still not adequate infrastructure to support students for their technopreneurship activity students only learning in classes and there is hasn't been an institution that provides incubation and guidance for students that wanted to start their business in technology therefore there is a need to build an institution which can support students and giving them guidance to increase the success of new technopreneurship.

\section{Conclusion and Future Research}

As many as $52.15 \%$ of students did not continue their innovation products because they did not get access to funding, $13.50 \%$ of students did not continue their innovation products because they did not know what to do and did not get technical guidance. $11.66 \%$ of students want to graduate on time, $10.44 \%$ do not get a mentor/coach who knows how to develop and can guide students well to get technopreneurship, $6.75 \%$ of students answered that there is no incubation platform like in universities Another high, 5.5\% of students do not dare to take risks to enter the world of technopreneurship. Variables that affect the success of incubation are infrastructure, duration of incubation, technical guidance, and mentor/coach for successful incubation. Based on the simulation results that have been designed, the variable that most influences the success of incubation is infrastructure because the success of incubation increases by $27.46 \%$ if students are provided with adequate infrastructure. The follow up model in figure 3 has been design to help students to continue their products to transform it into business by giving guidance and providing infrastructure so students can get funded and starting their successful business.

Meaning if we wanted to create new technopreneurships in Universitas Sumatera Utara we need to give them more adequate infrastructure so they can focus on their innovation and get funded.

The model developed in this study focuses on the strategy of developing technopreneurships at the Universitas Sumatera Utara with the aim of increasing the incubation of technopreneurships at the Universitas Sumatera Utara with indicators namely and increasing the number of products 
that receive funding. Other success indicators are needed, so that the results obtained are more comprehensive so that they can produce different strategies. The model needs to be developed more broadly and made more general in nature, so that research results in the form of policy strategies can be used for all Industrial Incubators.

\section{REFERENCES}

[1] Depositario D. P. T., Aquino N. A., \& Feliciano K.C,. "Entrepreneurial skill development needs of potential agri-based technopreneurships," ISSAAS, vol. 17, no. 1, pp. 106-120. 2011.

[2] Guadix, Jose., Carillo-Castrillo, Jesus., Onieva, Luis., Navascus, Javier, "Success variables in science and technology parks," Journal of Business Research. 2016.

[3] Hamdan, "Model inkubator bisnis untuk menumbuhkan kompetensi kewirausahaan," Jurnal Penelitian Pendidikan, vol.14, no.1, pp. 87-96. 2013.

[4] Dewanto, Indahwati, N., \& Handajani, S, "Strategies to Develop Technopreneurship-ship in College (Best Practices in the Implementation of Community Service Through the Entrepre-neurship Development Program Scheme)," Jurnal Pemberdayaan Masyarakat Madani (JPMM), vol. 5, no. 2, pp. 242-257. 2021

[5] Aerts, K., Matthyssens, P., and Vandenbempt, K, "Critical Role and Screening Practices of European Business Incubators," Technovation, vol. 27, no. 5, pp. 254-267. 2007.

[6] Wang, Z., He, Q., Xia, S., Sarpong, D., Xiong, A., \& Maas, G, "Capacities Of Business Incubator and Regional Innovation Performance,” Technological Forecasting and Social Change, pp. 1-44. 2020

[7] Mopangga, Herwin, "Studi Kasus Pengembangan Wirausaha Berbasis Teknologi (technopreneruship) Di Provinsi Gorontalo," Jurnal Trikonomika, vol. 14, no.1, pp. 1324. 2015.

[8] Kurniawan, Fajar, "Implementasi sistem dinamik pada pengembangan pola kemitraan industri kecil dan menengah di DKI Jakarta," INASEA, vol. 9, no. 2, pp. 129-138. 2008

[9] Mopangga, Herwin, "Studi Kasus Pengembangan Wirausaha Berbasis Teknologi (technopreneruship) Di Provinsi Gorontalo," Jurnal Trikonomika, vol. 14, no.1, pp.1324. 2015.

[10] Wicaksana, Danis Eka Prasetya, Kerangka sistem pengembangan perusahaan pemula berbasis teknologi luaran perguruan tinggi: studi kasus PIT UNS. Penerbit UNS, Surakarta, 2016. 
[11] Wulung, R.B. Seno., Takahashi, Katsuhiko., Morikawa, Katsumi, "An Integrated Technology and Financial Support Model in Technology Incubator," International Conference on Responsible Innovation \& Entrepreneurship. 2013.

[12] Widyarini, Lidya Ari., Lasdi, Ladovicus., Mulia, Teodora Winda, "Faktor- faktor yang mempengaruhi technopreneruship di UNIKA Widya Mandala Surabaya," Seminar Nasional Kewirausahaan dan Inovasi Bisnis. 2012.

[13] Somsuk, Nisakorn., Wonglimpiyarat, Jarunee., Laosirihongthong, "Technology Business Incubators and Industrial Development: Resources- Based View," Journal of Industrial Management and Data Systems, vol. 112, no.2, pp. 245-267. 2011. 